\title{
UJI ANTIOKSIDAN EKSTRAK HEKSANA, ETIL ASETAT, ETANOL, METANOL 80\% DAN AIR DAUN KELOR (Moringa oleifera, Lamk)
}

\author{
Agung Abadi Kiswandono ${ }^{1 *}$, Mamay Maslahat ${ }^{2}$ \\ ${ }^{1}$ Universitas Prima Indonesia, Medan \\ 2 Jurusan Kimia FMIPA Universitas Nusa Bangsa, Bogor \\ Jl. K. H. Sholeh Iskandar, Cimanggu, Tanah Sareal-Bogor 16166 \\ *e-mail : nau_shila@yahoo.com
}

\author{
ABSTRACT \\ Antioxidant Test of Hexane, Etil Asetat, Ethanol, Methanol $80 \%$ and \\ Water Extract in Moringa oleifera \\ By. Agung Abadi Kiswandono and Mamay Maslahat
}

\begin{abstract}
Antioxidant is a substance that can protect a materials from its destruction. Sources of antioxidant could be from plants. Alkaloid compounds in the Moringa oleifera leaves have potential antioxidant source. This research aimed to examine antioxidant potential from Moringa oleifera leaves extract of hexane, ethyl acetate, methanol $80 \%$ and water. The extraction methodes was meseration, and antioxidant test used the DPPH free radical scavenging effect. The result showed that extract ethanol had the best potential antioxidant with the value of $118.19 \mu \mathrm{g} / \mathrm{mL}$ and $R^{2}$ was $99.9 \%$, from hexanes was $692.39 \mu \mathrm{g} / \mathrm{mL}\left(R^{2}=99.9 \%\right)$, in ethyl acetate was $247.5 \mu \mathrm{g} / \mathrm{mL}\left(R^{2}=99.9 \%\right)$, in methanol $80 \%$ was $121.79 \mu \mathrm{g} / \mathrm{mL}\left(R^{2}=0.998\right)$ and in water extract $189.21 \mu \mathrm{g} / \mathrm{mL}\left(R^{2}=99.8 \%\right)$. Antioxidant standart as kuersetin that gave value of $15.84 \mu \mathrm{g} / \mathrm{mL}\left(R^{2}=99.9 \%\right)$.
\end{abstract}

Keywords : Bioactives compound, moringa oleifera, antioxidant

\begin{abstract}
ABSTRAK
Antioksidan merupakan substansi yang dapat mencegah atau memperlambat kerusakan suatu zat. Sumber antioksidan dapat diperoleh dari suatu tumbuhan. Senyawa alkaloid yang terdapat pada daun kelor berpotensi sebagai sumber antioksidan. Penelitian ini bertujuan menguji antioksidan ekstrak heksana, etil asetat, etanol, metanol 80\% dan air pada daun kelor (Moringa oleifera, Lamk). Penelitian dilakukan dengan menggunakan metode maserasi dan uji antioksidan menggunakan metode "DPPH free radical scavenging effect". Hasil uji antioksidan terbaik terdapat pada ekstrak etanol, yaitu sebesar $118.19 \mu \mathrm{g} / \mathrm{mL}$ dengan harga $\mathrm{R}^{2}$ sebesar $99.9 \%$, sedangkan pelarut yang lain, yaitu pelarut heksana sebesar $692.39 \mu \mathrm{g} / \mathrm{mL}\left(\mathrm{R}^{2}=99.9 \%\right)$, etil asetat $247.5 \mu \mathrm{g} / \mathrm{mL}\left(\mathrm{R}^{2}=99.9 \%\right)$, metanol $80 \%$ $121.79 \mu \mathrm{g} / \mathrm{mL}\left(\mathrm{R}^{2}=0.998\right)$ dan air $189.21 \mu \mathrm{g} / \mathrm{mL}\left(\mathrm{R}^{2}=99.8 \%\right)$, sebagai pembanding antioksidan digunakan kuersetin, yaitu $15.84 \mu \mathrm{g} / \mathrm{mL}$ $\left(\mathrm{R}^{2}=99.9 \%\right)$.
\end{abstract}

Kata kunci : Senyawa bioaktif, moringa oleifera, antioksidan

\section{PENDAHULUAN}

Antioksidan adalah suatu substansi yang dapat mencegah atau memperlambat kerusakan substansi dengan cara peroksidasi. Sumber antioksidan dapat berasal dari dalam tubuh atau dapat juga berasal dari luar tubuh. Antioksidan yang berasal dari luar tubuh dapat diperoleh dari tumbuhan yang mengandung senyawa alkaloid (Benabdesselam et.al. 2007). Flavonoid, fenol hidrokuinon, tanin juga telah banyak dilaporkan memiliki aktivitas antioksidan (Pratt and Hudson 1990). Senyawa tersebut berperan sebagai antioksidan dengan cara menghambat peroksida lipid sehingga dapat melindungi tubuh dari penyakit kanker.

Beberapa penelitian menyatakan bahwa tumbuhan Moringa oleifera L mempunyai kandungan bioaktivitas dan berfungsi sebagai antiinflamasi (Sashidhara et al. 2007), dan antibiotik (Eilert et al. 1981).

Kumar dan Pari (2003) menyatakan bahwa ekstrak batang Moringa oleifera L mempunyai efek yang bersifat menurunkan peroksida lipid pada hati dan meningkatkan aktivitas antioksidan. Chumark et al. dalam penelitiannya terhadap daun Moringa oleifera L yang diambil dari Propinsi Trang, Thailand, menunjukkan bahwa ekstrak air panas Moringa oleifera L mempunyai aktivitas sebagai antioksidan secara in vivo dan ex vivo. Pengujian aktivitas antioksidan ini dilakukan dengan metode DPPH free radical scavenging effect.

Senyawa aktif antioksidan menghasilkan tingkat hambatan inhibition concentration $\left(\mathrm{IC}_{50}\right)$. $\mathrm{IC}_{50}$ adalah konsentrasi antioksidan $(\mu \mathrm{g} / \mathrm{ml})$ yang mampu menghambat 50\% radikal bebas. Semakin 
banyak radikal bebas yang dihambat oleh antioksidan, maka semakin kecil $\mathrm{IC}_{50}$. Nilai $\mathrm{IC}_{50}$ diperoleh dengan membandingkan serapan radikal bebas sebelum dan sesudah direaksikan dengan antioksidan yang terdapat dalam zat uji untuk setiap konsentrasi. Ekstrak dikatakan aktif sebagai antioksidan jika memiliki $\mathrm{IC}_{50}$ kurang dari 100 $\mu \mathrm{g} / \mathrm{mL}$.

\section{METODE PENELITIAN}

\section{Bahan}

Sampel daun kelor diambil pada bulan Maret 2008 dari desa Cikarang kecamatan Dramaga Bogor, etanol, metanol, etil asetat, heksan, kuersetin, pereaksi 1,1-difenil-2-pikrilhidrazil, kertas saring, aquades, aluminium foil, kapas bebas lemak dan tissue.

\section{Peralatan}

Peralatan yang digunakan adalah satu set alatalat gelas, alat ekstraksi maserasi, oven, rotary evavorator, blender, neraca analitik, desikator, refrigerator.

\section{Prosedur Kerja}

Sampel daun kelor yang didapatkan, kemudian dibersihkan dari kotoran-kotoran dan dikeringkan di udara terbuka pada suhu kamar. Sampel yang telah kering (mengandung kadar air \pm $10 \%$ ) lalu dihaluskan dengan menggunakan blender, lalu dilakukan proses maserasi.

Sebanyak 400 - 500 g sampel kering yang telah dihaluskan dimaserasi dengan heksana sampai bebas lemak ditandai dengan larutan yang telah jernih. Ekstrak yang dihasilkan disaring, kemudian filtratnya di pekatkan dengan menggunakan labu penguap putar pada suhu $40^{\circ} \mathrm{C}$ sehingga diperoleh ekstrak kasar. Ampasnya dikering anginkan lalu setelah kering, dimaserasi kembali selama 1 minggu dengan berturut-turut menggunakan etil asetat, etanol, metanol $80 \%$ dan terakhir dengan air dengan cara yang sama seperti heksana. Filtrat yang dihasilkan lalu dipekatkan dan didapatkan ekstrak kasar kemudian uji antioksidan terhadap ekstrak heksana, etil asetat, methanol $80 \%$ dan air yang dihasilkan menggunakan metode DPPH free radical scavenging effect.

\section{$\underline{\text { Uji Antioksidan }}$}

\section{Pembuatan larutan blanko}

Larutan yang digunakan adalah metanol. Pembuatan larutan blanko dilakukan dengan cara memipet $800 \mu \mathrm{L}$ metanol, kemudian dimasukkan ke dalam tabung reaksi, ditambah $200 \mu \mathrm{L}$ larutan DPPH lalu dikocok sampai homogen, inkubasi pada suhu ruang selama 30 menit.

\section{Pembuatan Larutan Kuersetin}

a. Pembuatan larutan induk $1000 \mu \mathrm{g} / \mathrm{mL}$, sebanyak $1.0 \mathrm{mg}$ kuersetin ditimbang dan dilarutkan dalam $1 \mathrm{~mL}$ metanol, kemudian dikocok hingga homogen.

b. Pembuatan larutan seri 10, 50, 100 dan 200 ppm, Inkubasi pada suhu kamar selama 30 menit, setelah itu ditambahkan $1 \mathrm{~mL}$ metanol dan dikocok kembali hingga homogen. Setelah itu diukur absorbansinya dengan menggunakan spektrofoto meter UV-VIS pada $\lambda: 515 \mathrm{~nm}$.

\section{Persiapan Larutan Bahan Uji}

a. Pembuatan larutan induk bahan uji $1000 \mu \mathrm{g} / \mathrm{mL}$ Sebanyak $1.0 \mathrm{mg}$ ekstrak ditimbang dan dilarutkan dalam $1 \mathrm{~mL}$ metanol, kemudian dikocok hingga homogen

b. Pembuatan larutan seri 10, 50, 100 dan 200 ppm, Inkubasi pada suhu kamar selama 30 menit, setelah itu ditambahkan $1 \mathrm{~mL}$ metanol dan dikocok kembali hingga homogen. Setelah itu diukur absorbansinya dengan menggunakan spektrofotometer UV-VIS pada $\lambda: 515 \mathrm{~nm}$.

\section{Perhitungan}

a. Pengukuran aktivitas antioksidan dihitung dengan rumus sebagai berikut :

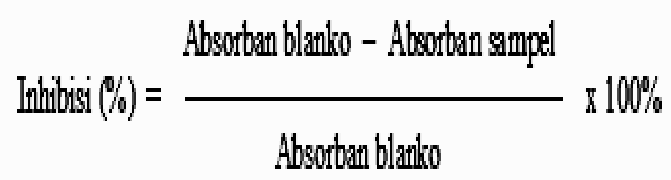

Inhibisi adalah besar aktivitas yang dihasilkan oleh sampel. 
b. Perhitungan $\mathrm{IC}_{50}$ dengan menggunakan regresi linier $\mathrm{Y}=\mathrm{a}+\mathrm{bX}$

$$
\begin{aligned}
& b=\frac{n \Sigma\left(X_{1} Y_{i}\right)-\Sigma x i \Sigma Y_{i}}{n \Sigma X_{1}^{2}-(\Sigma x i)^{2}} \quad a=\frac{\Sigma Y_{i}-b \Sigma X_{1}}{n} \\
& \mathrm{r}=\sqrt{\frac{n \Sigma\left(\mathrm{X}_{1} \mathrm{Y}_{\mathrm{i}}\right)-\Sigma\left(\mathrm{X}_{i}\right)\left(\mathrm{Yi}_{\mathrm{i}}\right)}{\Sigma \mathrm{X}_{1}^{2}-\left(\sum \mathrm{xi}^{2}\right)\left(n \Sigma \mathrm{Yi}^{2}\right)-\left(\sum \mathrm{yi}\right)^{2}}}
\end{aligned}
$$

Keterangan :

Yi : Inhibisi

$\mathrm{Xi}$ : Konsentrasi larutan uji

a : Harga intersep yang menunjukkan faktor kesalahan sistematis

b : Harga slope yang menunjukkan hubungan antara perubahan absis dan ordinat

$\mathrm{r}$ : Koefisien korelasi Nilai $\mathrm{IC}_{50}$ dicari dengan menggunakan regresi linier $\mathrm{Y}=\mathrm{a}+\mathrm{bX}$

Keterangan :

$\mathrm{Y}: 50$

$\mathrm{X}: \mathrm{IC}_{50}$

a : Harga intersep yang menunjukkan faktor kesalahan sistematis

b : Harga slope yang menunjukkan hubungan antara perubahan absis dan ordinat

$\mathrm{IC}_{50}$ pada uji antioksidan artinya adalah konsentrasi larutan uji yang dapat menghambat $50 \%$ radikal bebas DPPH.

\section{HASIL DAN PEMBAHASAN}

Sampel yang digunakan pada penelitian ini merupakan bahan yang berasal dari tumbuhtumbuhan, sehingga sampel mengandung air dalam jumlah relatif tinggi. Oleh karena itu, dalam tahap persiapan sampel harus dilakukan penentuan kadar air yang terkandung dalam sampel, karena akan mempengaruhi daya tahan bahan pangan terhadap serangan atau aktivitas mikroorganisme.

Kadar air ditetapkan dengan cara gravimetri, yaitu diperoleh dengan cara menghitung bobot bahan sebelum dan sesudah dikeringkan pada temperatur di atas titik didih air, sehingga diharapkan semua air akan menguap pada suhu tersebut dan pada periode waktu tertentu. Kadar air pada sampel diperoleh sebesar $9.67 \%$.
Ekstrak kasar pada penelitian ini diperoleh dengan cara perendaman (maserasi) sampel. Mekanisme metode maserasi adalah proses difusi pelarut ke dalam dinding sel tumbuhan untuk mengekstrak senyawa-senyawa yang ada dalam tumbuhan tersebut. Metode maserasi digunakan untuk mengekstrak senyawa yang kurang tahan terhadap panas, biasanya digunakn untuk sampel yang belum diketahui karakterisasi senyawanya.

Pelarut yang digunakan adalah heksana, etil asetat, etanol, metanol dan terakhir menggunakan air. Pemisahan pertama terhadap sampel digunakan pelarut heksana dengan tujuan untuk memisahkan senyawa-senyawa non polar termasuk lemak yang terkandung pada sampel. Kemudian larutan yang dihasilkan di kentalkan menggunakan vakum evaporator untuk mendapatkan ekstrak kental. Ampas dari ekstraksi lalu dikeringkan dan di lakukan ekstraksi kembali menggunakan pelarut berturut-turut etil asetat, etanol, metanol dan terakhir dengan air.

Ekstrak kasar yang dihasilkan dari masingmasing pelarut kemudian diuji aktivitas antioksidan. Pada penelitian ini aktivitas antioksidan diukur dengan metode DPPH Free Radical Scavenger.

DPPH merupakan senyawa radikal bebas yang stabil. Uji aktivitas antioksidan dengan menggunakan DPPH, prinsipnya adalah penangkapan hidrogen dari antioksidan oleh radikal bebas DPPH (warna ungu) dan diubah menjadi 1,1difenil-2-pikrilhidrazin (warna kuning), kemudian sisa DPPH diukur intensitas warna ungunya pada panjang gelombang $515 \mathrm{~nm}$. Reaksi uji antioksidan disajikan pada Gambar 1.

Nilai $\mathrm{IC}_{50}$ dari Ekstrak etanol adalah yang terkecil dari ke 5 ekstrak yang dilakukan pada penelitian ini, yaitu $118.19 \mu \mathrm{g} / \mathrm{mL}$ dengan harga $\mathrm{R}^{2}$ $=0,9996$ (Gambar 3), disusul kemudian oleh pelarut lainnya. Pelarut tersebut adalah metanol $80 \%$ sebesar $121,79 \mu \mathrm{g} / \mathrm{mL}$ (Gambar 4), pelarut air sebesar 189,21 $\mu \mathrm{g} / \mathrm{mL}$ (Gambar 5), pelarut etilasetat sebesar 247,5 $\mu \mathrm{g} / \mathrm{mL}$ (Gambar 6) dan pelarut heksana sebesar $692,39 \mu \mathrm{g} / \mathrm{mL}$ dengan harga $R^{2}=$ 99,5\% (Gambar 7). Standar antioksidan yang digunakan sebagai pembanding adalah kuersetin dengan nilai 15,84 $\mu \mathrm{g} / \mathrm{mL}$ (Gambar 2). Ekstrak dikatakan aktif sebagai antioksidan jika memiliki $\mathrm{IC}_{50}$ kurang dari $100 \mu \mathrm{g} / \mathrm{mL}$ (Artanti et.al. 2000), artinya bahwa kandungan senyawa-senyawa yang mampu meredam radikal bebas DPPH pada sampel daun kelor adalah sedikit (kandungannya sedikit). 
<smiles>CCCCN(CC)c1c([N+](=O)[O-])cc([N+](=O)[O-])cc1[N+](=O)[O-]</smiles>

1,1-difenil-2-pikrilhidrazil

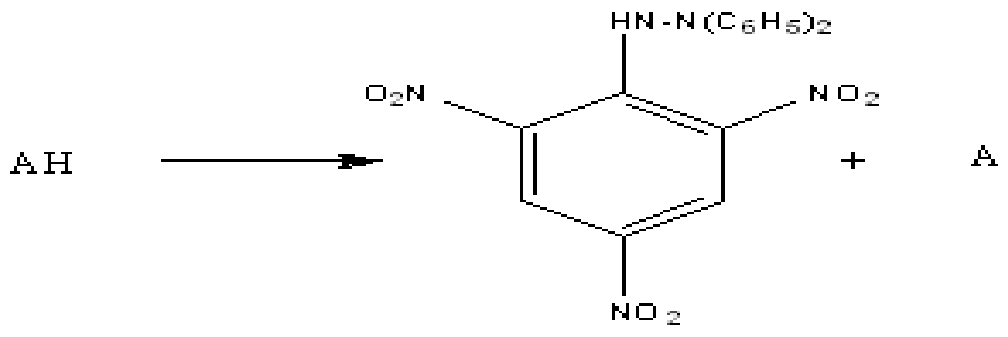

1,1-difenil-2-pikrilhidr azin

Gambar 1. Reaksi Uji Antiosidan

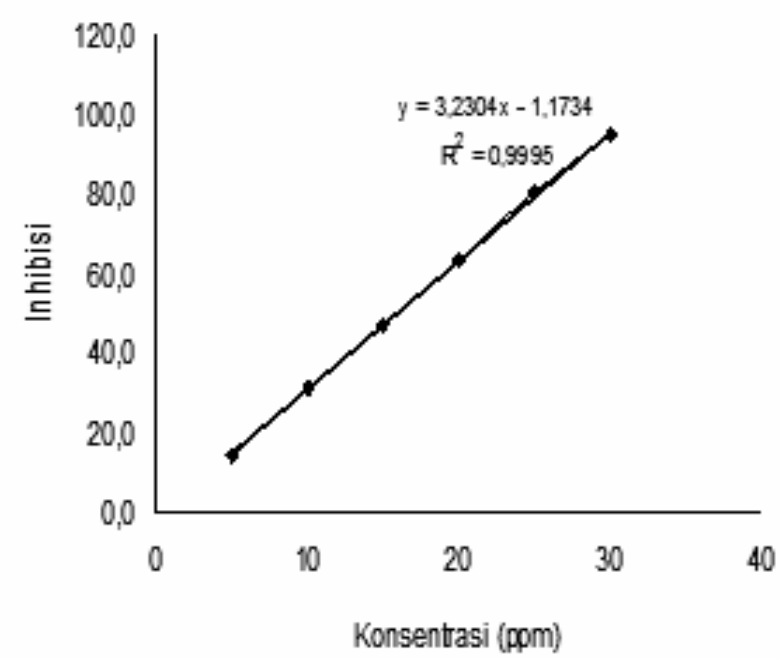

Gambar 2. Kurva S tandar Aktifitas Antioksidan Kuersetin

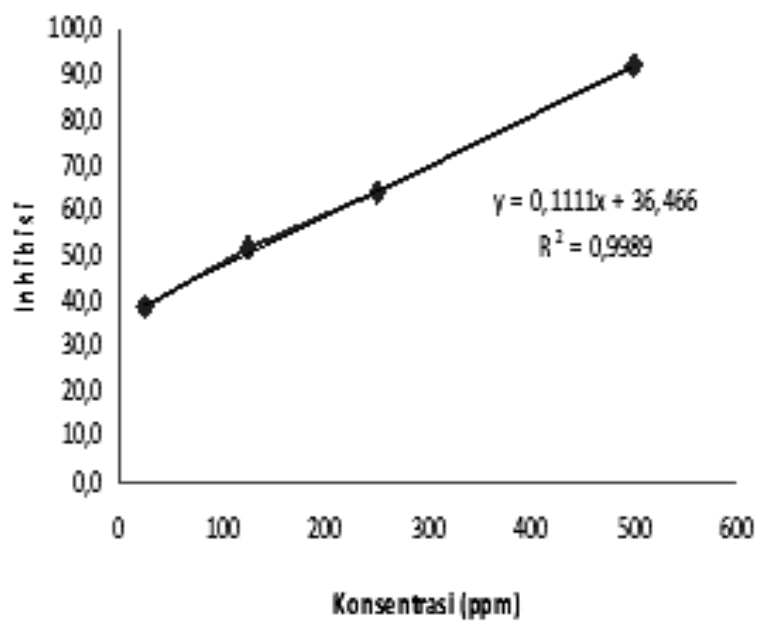

Gambar 4. Hasil Uji Aktifitas Antiolcsidan Elcstrak Metanol $80 \%$ pada Daun Kelor

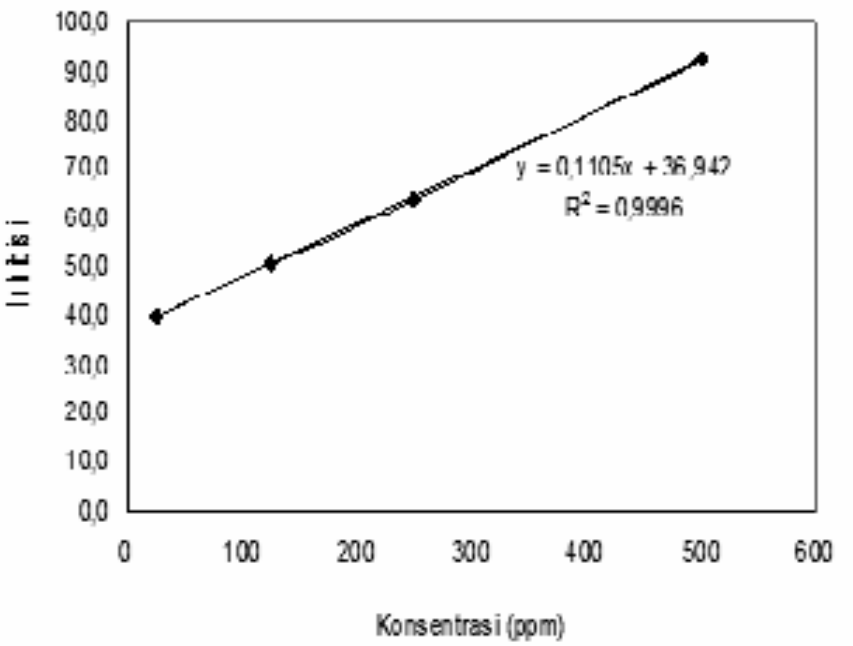

Gambar 3. Hasil Uji Aktifitas Antioksidan Elestrak Etanol pada Daun Kelor

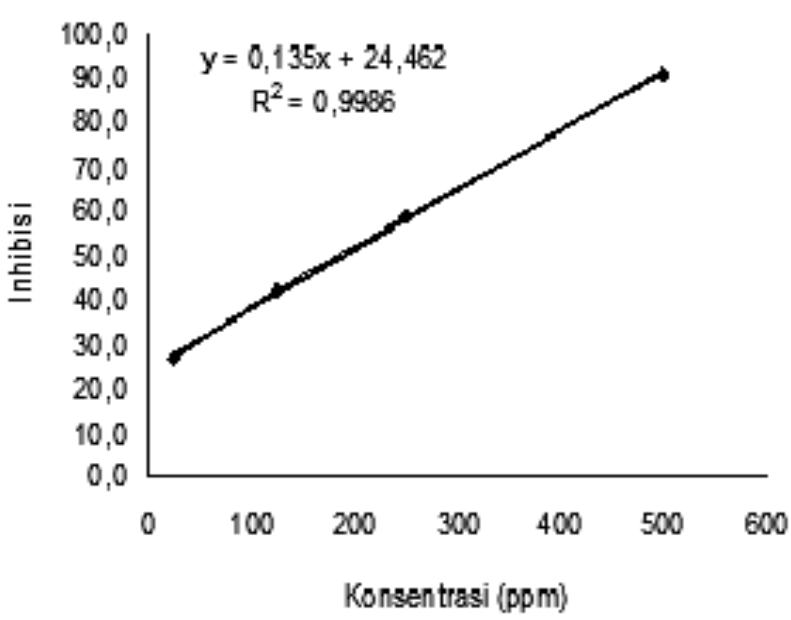

Gambar 5. Hasil Uji Aktifitas Antioksidan Elcstrak Air pada Daun Kelor 


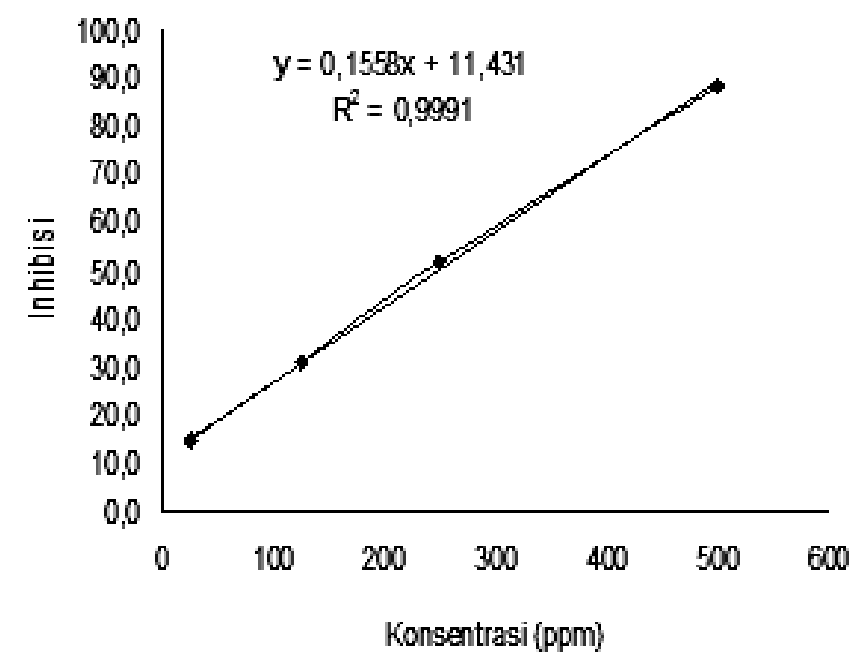

Gambar 6. Hasil Uji Alctifitas Antiolcsidan Elcstrake Etil-Asetat pada Daun Kelor

\section{KESIMPULAN}

Hasil penelitian menunjukan bahwa uji antioksidan terbaik terdapat pada ekstrak etanol, yaitu sebesar $118,19 \mu \mathrm{g} / \mathrm{mL}$ dengan harga $\mathrm{R}^{2}$ sebesar $99.9 \%$, sedangkan pelarut yang lain, yaitu pelarut heksana sebesar $692.39 \mu \mathrm{g} / \mathrm{mL}\left(\mathrm{R}^{2}=99.9 \%\right)$, etil asetat $247.5 \mu \mathrm{g} / \mathrm{mL}\left(\mathrm{R}^{2}=99.9 \%\right)$, metanol $80 \%$ $121.79 \mu \mathrm{g} / \mathrm{mL}\left(\mathrm{R}^{2}=0.998\right)$ dan air $189.21 \mu \mathrm{g} / \mathrm{mL}$ $\left(\mathrm{R}^{2}=99.8 \%\right)$, sebagai pembanding antioksidan digunakan kuersetin, yaitu $15.84 \mu \mathrm{g} / \mathrm{mL} \quad\left(\mathrm{R}^{2}\right.$ $=99.9 \%$ ).

\section{DAFTAR PUSTAKA}

Artanti, N. et al. Evaluasi Aktivitas Antioksidan Berbagai Ekstrak Daun Benalu (Dendrophthoe pentandra L) yang Tumbuh pada Inang Belimbing dan mangga. Laporan Penelitian. Pusat Penelitian Kimia LIPI. Hal 1-7.

Benabdesselam, FM. et. al. 2007. Antioxidant Activities of Alkaloid Extracts of Two Algerian Species of Fumaria : Fumaria Capreolatan and Fumaria bastard. ACG Publication rec.nat.Prod $1: 28-35$.

Budiman, A. 2001. Senyawa Bioaktif Golongan Kumarin Artemisia Sacrorum Ledeb. Skripsi. Bogor : FMIPA. IPB.

Dalimarta, S. 2003. Karakteristik Tumbuhan Obat. Prosiding Seminar dan Pameran Nasional Tumbuhan Obat Indonesia

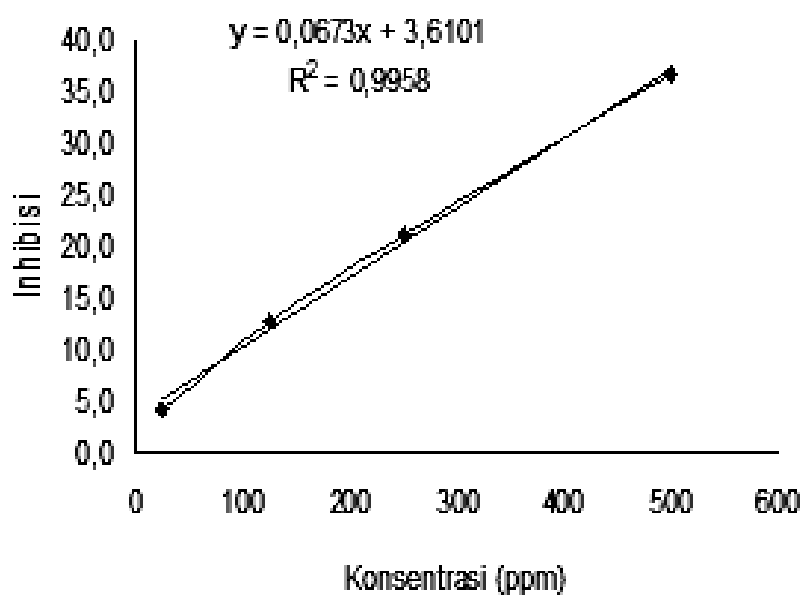

Gambar 7. Hasil Uji Aktifitas Antiolcsidan Elcstrak Helcsana pada Daun Kelor

XXIV. Pusat Studi Biofarmaka IPB. Bogor.

Eilert U, et. al. 1981. The Antibitic Principle of Seeds of Moringa oleifera and moringa stenopetala. J. Medicinal Plant res. 42 (55-61).

Harborne, J. B. 1996. Metode Fitokimia. Cara modern menganalisa Tumbuhan. Terjemahan Kosasih Patmawinata dan Iwang Soediro. Edisi ke 3. Penerbit ITB. Bandung.

Hermawan, H. 2002. Isolasi dan Pencirian Senyawa Aktif dari Tumbuhan Anting-anting (Acalypha indica L.) yang Berpotensi Menurunkan Kadar Glukosa Darah. Skripsi. FMIPA. IPB. Bogor.

Hidayat MG. 2004. Perbandingan Metode Ekstraksi Flavonoid dan Terpenoid dari Sidaguri Serta Daya Inhibisi Ekstrak Terhadap Aktivitas Xantin Oxidase. Skripsi. FMIPA. IPB. Bogor.

Joni, MS, M. Sitorus, Nelly Katharina. 2008. Cegah Malnutrisi Dengan Kelor. Yogyakarta. Penerbit Kanisius.

Prat DE, BJF. Hudson. 1990. Natural Antioxidant not Exploited Commercially. Di dalam BJF Hudson. Editor Food Antioxidant. London. Elsevier Science. 
Putri, LD. 2004. Pemisahan dan Pencirian Pektin Dari Kulit Buah Kakao. Skripsi. FMIPA. IPB. Bogor.

Rafi, M. 2003. Identifikasi Fisik dan Senyawa Kimia Pada Tumbuhan Obat Fokus Untuk Tumbuhan Obat Diabites Melitus. Makalah Pelatihan Tanaman Tradisional (swamedikasi) Pengobatan Penyakit Diabites Melitus. Pusat Studi Biofarmaka. IPB. Bogor.

Sashidhara KV. et. al. 2007. Rare Dipeptida and Urea Derivatives from Roots of Moringa oleifera as Potential Anti-Inflammatory and Antinoniciceptive Agents. Short Communication Eurpean Journal of Medicinal Chemistry.

Sidik M. 1997. Antioksidan Alami Asal Tumbuhan. Prosiding Seminar Nasional Tumbuhan Obat Indonesia XII. ITB. Bandung.

Simanjuntak, P. 1988. Metode Isolasi dan Pemurnian Ekstrak Air dari Tumbuhan. Warta AKAB. 